\title{
Depth Integrated Microbial Community and Physico-Chemical Properties in Mangrove Soil of Sundarban, India
}

\author{
Subhajit Das ${ }^{1}$, Minati De ${ }^{2}$, Dipnarayan Ganguly ${ }^{1}$, Tushar Kanti Maiti ${ }^{3}$, Abhishek Mukherjee ${ }^{1}$, \\ Tapan Kumar Jana ${ }^{1}$, Tarun Kuma De ${ }^{1^{*}}$ \\ ${ }^{1}$ Department of Marine Science, Calcutta University, Kolkata, India \\ ${ }^{2}$ Maniktala Siksha Bhavan, Kolkata, India \\ ${ }^{3}$ Microbiology Laboratory, Department of Botany, Burdwan University, Burdwan, India \\ Email: * subhajit_310@yahoo.com, detarun@gmail.com
}

Received January 18, 2012; revised March 20, 2012; accepted June 5, 2012

\begin{abstract}
In the Sundarban Mangrove forest microbial activities are dominantly involved in both the mineralization and decomposition processes that regulate nutrient profile in soil of different depth. It was found that besides changing the water and soil quality, monsoonal cycle plays a crucial role in regulating microbial population distribution in the mangrove soil. Statistical analyses revealed that organic carbon was the most significant factor that regulated the total microbial population. The cellulose degrading bacteria, [mean value of CFU $14.32 \times 10^{6}$ (gm dry weight of soil $)^{-1}$ ] was dominant throughout the year. The sulfate reducing bacteria showed an increasing trend along depth with a minimum value at the surface i.e. $6.113 \times 10^{6}$ (gm dry weight of soil) ${ }^{-1}$ and $12.312 \times 10^{6}(\mathrm{gm} \text { dry weight of soil })^{-1}$ at a depth of $60 \mathrm{~cm}$. Intensification of monsoonal cycle could heavily affect microbe dominated soil biogeochemistry and subsequent change in the regional ecology of the Sundarban Mangrove Forest.
\end{abstract}

Keywords: Sundarban Mangrove; Microbial Population; Monsoonal Cycle; Nutrient Concentration

\section{Introduction}

Mangroves are highly productive marine ecosystem where bacteria actively take part in biomineralization and biotransformation of minerals [1]. The distribution of microbial activities in estuarine systems is clearly complex and variable. Much research remains to be done in order to define the distributions of microbial activities and the major factors involved in controlling these distributions in estuaries. Leaves and wood provided by mangrove plants to the soil are degraded primarily by large variety of microbes which actively participate in the heterotrophic food chain [2-4]. Major products of general recycling of organic matter are detritus which is rich in enzymes and proteins and contains large microbial population [5]. Bacteria are the major participants in the carbon, sulfur, nitrogen and phosphorous cycles in mangrove forest [6,7]. Bacterial activity is responsible for most of the carbon recycling in mangrove soil under both oxic and anoxic conditions. Many species of phosphate solubilizing rhizosphere bacteria associated with black mangrove roots were found. The mechanism for

"Corresponding author. phosphate solubilization probably involves the production of several organic acids [8]. Saprophytic fungi are fundamental to many aspects of decomposition and energy flow in mangrove forests [9]. Most investigations of anaerobic metabolism in natural ecosystem have dealt with sulfate rich marine soils where sulfate reduction is the dominating process or eutrophic lake soils where sulfate and nitrate are depleted in the hypolimnionn and in the superficial soil layers leaving terminal carbon mineralization principally to methane producing bacteria [10-12]. Sulfate reduction, methane production, denitrification are the important processes for the terminal electron removal during decomposition of organic matter in anoxic environment. The methanogens are characterized by their ability to produce methane from hydrogen and carbon di oxide, formate, acetate, methanol etc. [13]. Methanotrophs are a subset of a physiological group of bacteria known as methylotrophs. They are unique in their ability to utilize methane as a source of carbon and energy [14]. Nitrogen fixing bacteria are the other group of bacteria that are involved in formation of ammonia or organic nitrogen from atmospheric nitrogen. They may be free-living or symbiotic in Nature. It has been studied 
that $\mathrm{N}_{2}$ fixation by heterotrophic bacteria are generally regulated by specific environmental factors like Oxygen, combined Nitrogen and the availability of Carbon source for energy requirement [15]. Aerobic, autotrophic nitrifiers oxidize ammonia to nitrite and nitrate, with molecular oxygen as electron acceptor. Nitrite and nitrate are reduced to dinitrogen gas by heterotrophic denitrifying bacteria that use $\mathrm{NO}_{\mathrm{x}}$ instead of oxygen as electron acceptor [16]. The purpose of the present study was to examine seasonal and spatial variations in microbial population (bacteria and fungi) in mangrove soil and to find out the correlation between different microbes with nutrients.

\section{Materials and Methods}

\subsection{Study Area}

The Sundarban Mangrove Forest is located between $21^{\circ} 31^{\prime} \mathrm{N}$ and $22^{\circ} 30^{\prime} \mathrm{N}$ and longitude $88^{\circ} 10^{\prime} \mathrm{E}$ and $89^{\circ} 51^{\prime} \mathrm{E}$ along the North East coast of Bay of Bengal, India. This mangrove forest is a part of the estuarine system of the River Ganges, NE coast of Bay of Bengal (Figure 1). The climate in the region is characterized by the south- west monsoon (June-September), northeast monsoon or post-monsoon (October-January), and pre-monsoon (February-May); $70 \%$ - $80 \%$ of annual rainfall occurs during the summer monsoon (southwest monsoon), The tide in this estuarine complex is semidiurnal in nature with spring tide ranging between 4.27 and $4.75 \mathrm{~m}$ and neap tide range between 1.83 and $2.83 \mathrm{~m}$. It is a unique bioclimatic zone in between the land and ocean boundaries of the Bay of Bengal and the largest delta on the globe. The deltaic soil of Sundarban Biosphere Reserve comprises mainly saline alluvial soil consisting of clay, silt, fine sand and coarse sand particles.

\subsection{Sample Collections and Analyses}

Soil samples were collected aseptically using a handheld stainless steel core sampler $(3.2 \mathrm{~cm}$ diameter, 100 cm long) from six different depth i.e. 1) $0-10 \mathrm{~cm}$; 2) 10 - $20 \mathrm{~cm}$; 3) $20-30 \mathrm{~cm}$; 4) $30-40 \mathrm{~cm}$; 5) $40-50 \mathrm{~cm}$ and 6) $50-60 \mathrm{~cm}$ at five different sites in dense mangrove area (Deep forest) covering different seasons. Samples were collected into sterilized containers and immediately transported to the laboratory for analyses. Three replicates

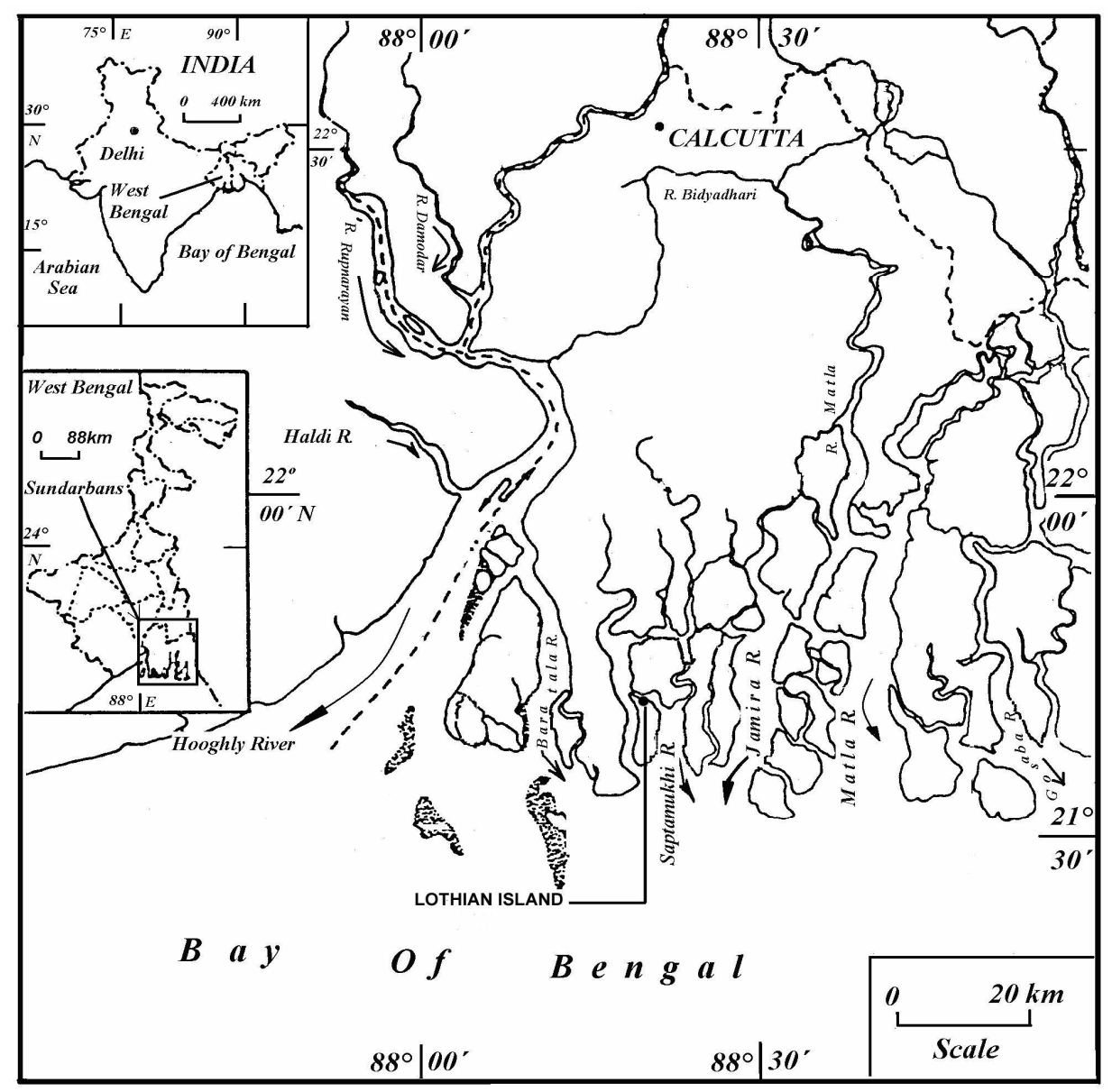

Figure 1. Map showing the study area. 
from each site were analyzed for five sites at different depths. The result represents the average value at each depth.

\subsection{Quantification of Bacteria and Fungi}

Soil samples were stored at $4^{\circ} \mathrm{C}$ immediately after collection and transported to the laboratory, for analysis with adequate care. $10 \mathrm{gm}$ of sample from different depth of different regions were homogenized with sterilized phosphate buffer solution. Serial dilutions up to $10^{-4}$ were made and inoculation was done with $0.1 \mathrm{ml}$. Quantification of bacteria and fungi from mangrove soils was carried out by spread plate method for different types of bacteria such as Phosphorous Solubilizing Bacteria (PSB), Cellulose Degrading Bacteria (CDB), nitrifying bacteria, free living nitrogen fixing bacteria and fungi and they were incubated at different conditions [17]. Sulfate reducing bacteria was cultured in Starkey's medium in anaerobic condition [18].

\subsection{Soil Quality Measurement}

Concentration of Nitrate-Nitrogen, Nitrite-Nitrogen, Phosphate-Phosphorous and Silicate in the soil sample was measured at $10 \mathrm{~cm}$ interval (from 0 to $60 \mathrm{~cm}$ depth). $30 \mathrm{~g}$ of soil subsample was collected from the different depth and was immediately extracted in $75 \mathrm{~mL}$ of $2 \mathrm{~mol} \cdot \mathrm{L}^{-1}$ potassium chloride $(\mathrm{KCl})$. The mixture was shaken until well mixed and allowed to stand overnight [16]. After 24 h, $4 \mathrm{~mL}$ of the supernatant was collected for the estimation of different nutrients using standard spectrophotometric methods [19]. Concentration of Sulfate-Sulphur of the soil was measured using standard protocol [20].
The $\mathrm{pH}$ value was measured in a 1:5 (w/w) soil water suspension using electric digital $\mathrm{pH}$ meter [21] and soil organic carbon was measured by standard methods [22]. Salinity of a soil saturation extract (ECe) was determined by measuring the electrical conductance of soil water saturation extract with the help of a conductivity meter [23]. Soil redox potentials (Eh) at each sampling site were measured with brightened platinum electrodes which were allowed to equilibrate in situ for $1 \mathrm{hr}$ prior to measurement. Each electrode was checked before use with quinhydrone in $\mathrm{pH} 4$ and 7 buffers $(\mathrm{mV}$ reading for quinhydrone is 218 and 40.8 , respectively, at $25^{\circ} \mathrm{C}$ ). The potential of a calomel reference electrode $(+244 \mathrm{mV})$ was added to each value to calculate Eh value for the soil samples [24].

\section{Result and Discussion}

Mangrove soil at Indian Sundarban showed seasonal variation with respect to both major nutrient concentrations and microbial population. Beside monsoonal influx of nutrients to the system, mangrove litters also played a significant role in regulating the nutrient status that in turn controlled the microbial population. Among several physical factors tidal inundation, wave action, presence of mangrove roots and bioturbation are the important ones considered for determining microbial abundance in the mangrove soil from surface to a depth up to $60 \mathrm{~cm}$. The physico-chemical parameters of the study are shown in Table 1. Temperature and Eh value of soil sample showed a decreasing trend from surface to 60 $\mathrm{cm}$ of depth during all season. A reverse profile was

Table 1. Seasonal variations of physico-chemical parameters of soil at different depth in Sundarban mangrove environment.

\begin{tabular}{|c|c|c|c|c|c|c|c|c|}
\hline Season & Parameters (soil) & $0 \mathrm{~m}$ & $10 \mathrm{~m}$ & $20 \mathrm{~m}$ & $30 \mathrm{~m}$ & $40 \mathrm{~m}$ & $50 \mathrm{~m}$ & $60 \mathrm{~m}$ \\
\hline \multirow{3}{*}{ Pre-monsoon } & $\mathrm{Eh}(\mathrm{mV})$ & -95 & -100 & -105 & -112 & -125 & -135 & -145 \\
\hline & Temp $\left({ }^{\circ} \mathrm{C}\right)$ & 17.85 & 17.84 & 17.83 & 17.82 & 17.82 & 17.78 & 17.78 \\
\hline & Salinity (PSU) & 16.80 & 16.96 & 17.05 & 17.20 & 17.35 & 17.40 & 17.60 \\
\hline \multirow{4}{*}{ Monsoon } & $\mathrm{Eh}(\mathrm{mV})$ & -100 & -102 & -110 & -118 & -145 & -170 & -175 \\
\hline & $\mathrm{pH}$ & 8.22 & 8.20 & 8.15 & 8.14 & 8.13 & 8.12 & 8.12 \\
\hline & Temp $\left({ }^{\circ} \mathrm{C}\right)$ & 24.71 & 24.69 & 24.67 & 24.65 & 24.60 & 24.59 & 24.59 \\
\hline & Salinity (PSU) & 14.99 & 15.01 & 15.05 & 15.15 & 15.20 & 15.35 & 15.41 \\
\hline \multirow{4}{*}{ Post-monsoon } & $\mathrm{Eh}(\mathrm{mV})$ & -121 & -125 & -128 & -130 & -139 & -165 & -187 \\
\hline & $\mathrm{pH}$ & 8.42 & 8.35 & 8.32 & 8.30 & 8.25 & 8.22 & 8.19 \\
\hline & Temp $\left({ }^{\circ} \mathrm{C}\right)$ & 12.90 & 12.94 & 12.98 & 12.99 & 13.05 & 13.12 & 13.12 \\
\hline & Salinity (PSU) & 15.35 & 15.39 & 15.45 & 15.50 & 15.60 & 15.65 & 15.69 \\
\hline
\end{tabular}


found for $\mathrm{pH}$ and salinity. During monsoon, the salinity was found to be $14.99 \mathrm{psu}$ in surface soil and it was $15.41 \mathrm{psu}$ at $60 \mathrm{~cm}$ depth. Less soil salinity in monsoon with respect to pre monsoon and post monsoon may be due to maximum dilution by river run off during monsoon period [25]. Eh value showed a decreasing trend from surface soil $(-95 \mathrm{mV})$ to $60 \mathrm{~cm}$ of depth $(-145 \mathrm{mV})$ which represented more anoxicity of bottom soil than that of surface during premonsoon (Table 1). Soil redox potential value (Eh) from surface to $60 \mathrm{~cm}$ of depth region in three distinct seasons suggested that the soil of deep forest region of Sundarban Mangrove is relatively anoxic or it can be referred to as oxygen-starved soil. During pre-monsoon nutrient concentration showed very weak stratification from surface to $30 \mathrm{~cm}$ of depth with almost uniform distribution. Intense bioturbation up to 30 $\mathrm{cm}$ depth by several benthic organisms could cause uniform mixing of soil nutrients.

No significant variation of silicate concentration was found throughout the entire depth. Gradual decrease in organic carbon and Phosphate-Phosphorous concentration was observed from depths of 30 to $60 \mathrm{~cm}$.

During transportation of organic matter from surface to bottom, it is decomposed by microbes. As a result, organic content of soil decreased with increasing depth. It could be attributed to mangrove litter fall with an annual rate of $1603 \mathrm{~g} \cdot \mathrm{m}^{-2} \cdot$ year $^{-1}$ [26]. Organic carbon was found maximum during postmonsoon followed by pre monsoon and monsoon (Figure 2(a)). Nitrate-Nitrogen concentration was increased from surface to $40 \mathrm{~cm}$ of depth but decreased from $40 \mathrm{~cm}$ to $60 \mathrm{~cm}$. Vertical movement of materials, nutrient cycling and reuse driven by various burrowing organisms could have an effect on this Nitrate-Nitrogen distribution along the depth profile at up to $40 \mathrm{~cm}$. Less abundance of bioturbation below 40 $\mathrm{cm}$ could enhance the anoxic condition which in turn initiate denitrification causing sudden depletion of NitrateNitrogen. The Nitrite-Nitrogen concentration showed no significant variation throughout depth but slight increased below $50 \mathrm{~cm}$ of depth which may be an indication of denitrification. Population of SRB was found to increase with increase in depth in all seasons. Thus, more anoxic condition preferred the more population of SRB in the bottom soil than that of surface soil. Fungal population showed decreasing trend with increasing depth. Free living nitrogen fixing bacterial population showed decreasing trend from surface to $30 \mathrm{~cm}$ depth and increased again from $30 \mathrm{~cm}$ to $50 \mathrm{~cm}$ of depth. After the death of plant, the woods are carried away by tidal action or consumed by herbivorous animal but the root attached to the bottom soil below the $50 \mathrm{~cm}$ depth seldom may act as the source of Carbon to fungus and cellulose degrading bacteria (Figure 2(a)).

During monsoon Nitrate-Nitrogen, organic carbon content of soil showed decreasing pattern along with de- crease in population of nitrifying bacteria with increase in depth. Silicate concentration showed little variation with increasing depth. Population of PSB was found to be decreased with increase in depth and at the same time, Phosphate-Phosphorous concentration was also found to decrease with increase in depth. Population of CDB decreased with increase in depth as the organic carbon content of the soil was also found to decrease with increase in depth. Population of SRB showed increasing trend from surface to $60 \mathrm{~cm}$ of depth (Figure 2(b)).

During postmonsoon Nitrate-Nitrogen organic carbon content of soil showed decreasing pattern along with decrease in population of nitrifying bacteria with increase in depth. Silicate concentration showed little variation with increasing depth. Population of PSB was found to be decreasing with increasing depth and at the same time, Phosphate-Phosphorous concentration was also decreasing with increase in depth. Population of CDB decreased with increase in depth as the organic carbon content of the soil was also decreasing with increase in depth. Sulfate concentration did not show distinct stratification though population of SRB showed increase in trend from surface to bottom (Figure 2(c)). Free living nitrogen fixing bacteria showed decrease in population up to $30 \mathrm{~cm}$ of depth but below $30 \mathrm{~cm}$ to the next $30 \mathrm{~cm}$ of depth their population was recorded to increase. Population of PSB and free living nitrogen fixing bacteria was more in proportion than population of nitrifying bacteria. Organic carbon content of the soil was found to be most significant factor on the growth rate of cellulose decomposing bacteria (Pearson correlation of OrgC (\%) and C.D.B. $\left(\right.$ CFUs $\left.\times 10^{6}\right)=0.500$, P-Value $\left.=0.000\right)$. The populations of cellulose decomposing bacteria were found to be more in post monsoon period than that of premonsoon and monsoon. Again the zone with more population of phosphate solubilizing bacteria showed more concentration of available phosphate. Presence of phosphatase enzyme within such type of bacteria might be responsible for these findings [27]. It might be for availability of more organic carbon source. Sulfate reducing bacteria was found to be correlated with sulfate concentration of soil sample (Pearson correlation of Sulfate-Sulphur $\mathrm{mg} \cdot \mathrm{gm}^{-1}$ dry wt of soil and S.R.B. (CFUs $\times$ $10^{6}$ ) $=0.595$, P-Value $<0.001$ )

Phosphate solubilizing bacteria was also found to be correlated with phosphate concentration of the Sundarban mangrove soil (Pearson correlation of Phosphate-Phosphorous $\mu \mathrm{g} \cdot \mathrm{gm}^{-1}$ dry wt of soil and P.S.B. (CFUs $\times 10^{6}$ ) $=0.766$, P-Value $=0.000)$. No such correlation was found for nitrogen fixing bacteria with nitrate and nitrite concentration. Organic carbon from the leaves, wood from forest and other organic dead or waste products from other living creatures are easily degraded by cellulose degrading bacteria in the mangrove soil because they are the most dominating group of microbes prior to 


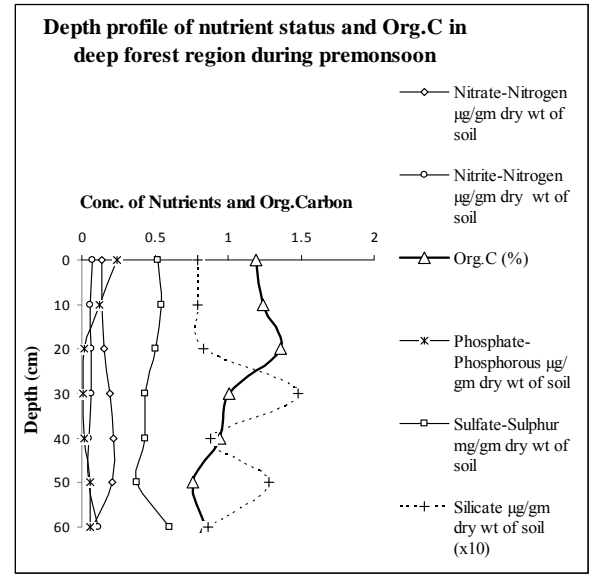

(1)

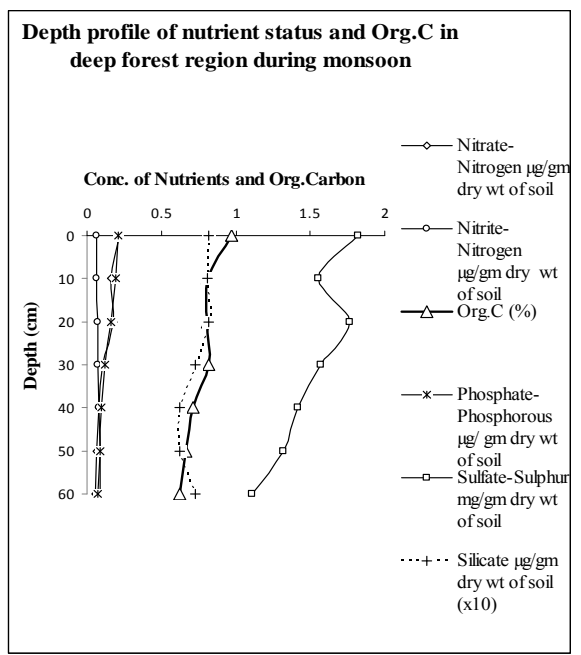

(1)

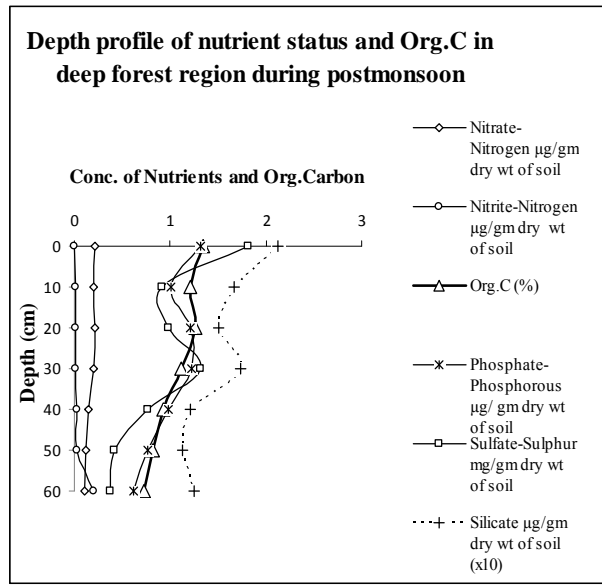

(1)

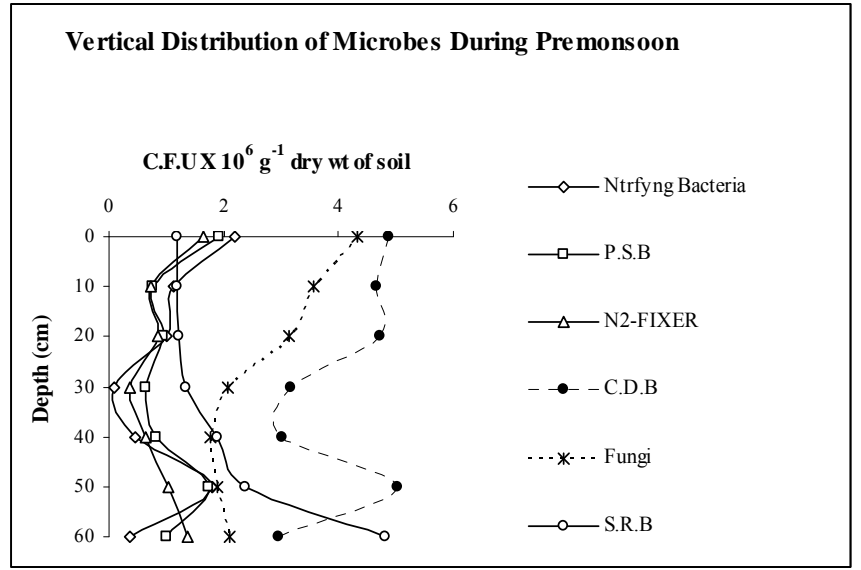

(2)

(a)

\section{Vertical Distribution of Microbes During Monsoon}

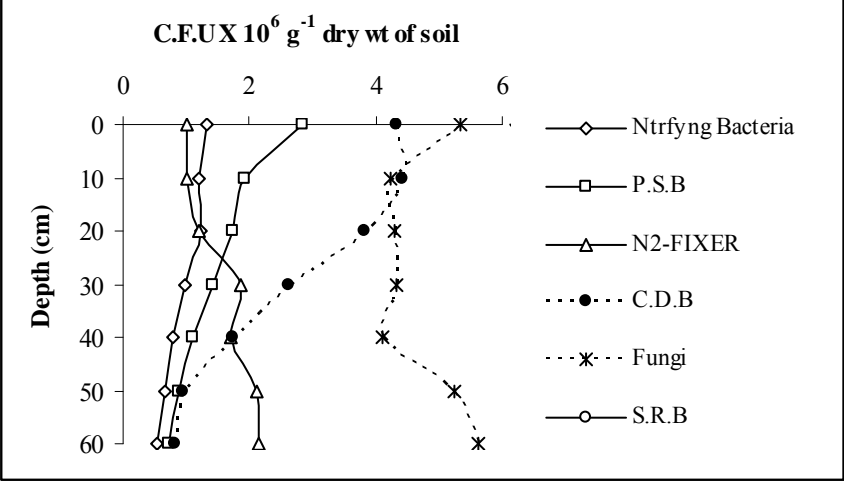

(2)

(b)

Vertical Distribution of Microbes During Postmonsoon

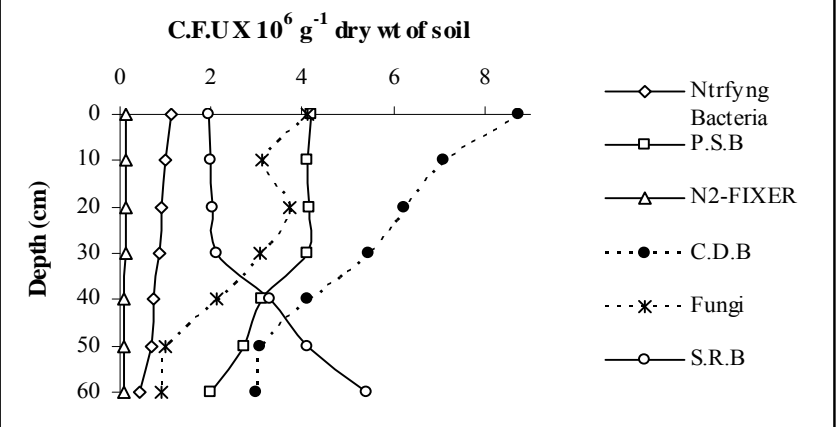

(2)

(c)

Figure 2. (a) Depth profile of organic carbon, nutrient concentrations (1) and microbial populations (CFUs) (2) during pre-monsoon at different depth; (b) Depth profile of organic carbon, nutrient concentrations (1) and microbial populations (CFUs) (2) during monsoon at different depth; (c) Depth profile of organic carbon, nutrient concentrations (1) and microbial populations (CFUs) (2) during post-monsoon at different depth. 
fungi. Other groups of microbes have also shown significant population which is a good sign for a mangrove forest with respect to mineralization of organic debris and as a result mangrove plants can easily get nutrients in their simplest forms. From seasonal perspective, the monsoon period was significantly different (Student's $t$ test, $\mathrm{P}<0.01$ ) than other periods of the year in terms of total bacterial abundance and other key parameters. Sea level rise due to global warming may hamper the stable ecological zone of Sundarban mangrove forest which may ultimately reflect to net flux of several biologically active trace gases between soil and atmosphere. Introduction of huge amount of nutrients during monsoon have a positive feedback on the bacterial population of mangrove sediment. Beside the changes in several physicochemical parameters, transport of huge amount of aquatic microbes could lead to the significant increase in the microbial population in the soil of this mangrove ecosystem. This may contribute to the aquatic biogeochemistry of this tropical wetland.

\section{Acknowledgements}

The financial assistance from DOEn, Govt. of West Bengal and U.G.C., New Delhi are gratefully acknowledged. The authors are also grateful to the Forest Department, Govt. of West Bengal for assisting the research team in collecting data and providing all infrastructural facilities to reach the remote island.

\section{REFERENCES}

[1] B. Gonzalez-Acosta, Y. Bashan, N. Y. Hernandez-Saavedra, F. Ascenaio and G. Cruz-Aguero, "Seasonal Seawater Temperature as the Major Determinant for Populations of Culturable Bacteria in the Soils of an Intact Mangrove in an Arid Region," FEMS Microbiology Ecology, Vol. 55, No. 2, 2006, pp. 311-321. doi:10.1111/j.1574-6941.2005.00019.x

[2] D. M. Alongi, K. G. Boto and F. Tirendi, "Effect of Exported Mangrove Litter on Bacterial Productivity and Dissolved Organic Carbon Fluxes in Adjacent Tropical Nearshore Soils," Marine Ecology Progress Series, Vol. 56, 1989, pp. 133-144. doi:10.3354/meps056133

[3] D. M. Alongi, P. Christofferson and F. Tirendi, "The Influence of Forest Type on Microbial-Nutrient Relationship in Tropical Mangrove Soil," Journal of Experimental Marine Biology and Ecology, Vol. 171, No. 2, 1993, pp. 201-223. doi:10.1016/0022-0981(93)90004-8

[4] D. M. Alongi, "The Role of Bacteria in Nutrient Recycling in Tropical Mangrove and Other Coastal Benthic Ecosystems," Hydrobiologia, Vol. 285, No. 1-3, 1994, pp. 19-32. doi:10.1007/BF00005650

[5] G. Holguin, Y. Bashan and P. Vazavez, "The Role of Soil Microorganism in the Productivity, Conservation and
Rehabilitation of Mangrove Ecosystem: An Overview," Biology of Fertile Soils, Vol. 33, No. 4, 2001, pp. 265278. doi:10.1007/s003740000319

[6] G. Toledo, Y. Bashan and A. Soeldner, "Cyanobacteria and Black Mangroves in Northwestern Mexico: Colonization, and Diurnal and Seasonal Nitrogen Fixation on Aerial Roots," Canadian Journal of Microbiology, Vol. 41, No. 11, 1995, pp. 999-1011. doi:10.1139/m95-139

[7] A. Rojas, G. Holguin, B. R. Glick and Y. Bashan, "Synergism between Phyllobacterium sp. $\left(\mathrm{N}_{2}\right.$-Fixer) and $\mathrm{Ba}$ cillus licheniformis (P-Solubilizer), both from a Semiarid Mangrove Rhizosphere," FEMS Microbiology Ecology, Vol. 35, 2001, pp. 181-187. doi:10.1111/j.1574-6941.2001.tb00802.x

[8] P. Vazquez, G. Holguin, M. E. Puente, A. Lopez-Cortes and Y. Bashan, "Phosphate-Solubilizing Microorganisms Associated with the Rhizosphere of Mangroves in a Semiarid Coastal Lagoon," Biology and Fertility of Soils, Vol. 30, No. 5-6, 2000, pp. 460-468. doi: $10.1007 / \mathrm{s} 003740050024$

[9] D. B. Nedwell, T. H. Blackburn and W. J. Wiebe, "Dynamic Nature of the Turnover of Organic Carbon, Nitrogen and Sulpher in the Soil of a Jamaican Mangrove Forest," Marine Ecology Progress Series, Vol. 110, No. 9, 1994, pp. 223-231. doi:10.3354/meps 110223

[10] E. Senior, E. B. Lindstrom, I. M. Banat and D. B. Nedwell, "Sulfate Reduction and Methanogenesis in the Sediment of a Saltmarsh on the East Coast of the United Kingdom," Applied Environmental Microbiology, Vol. 43, 1982, pp. 987-996.

[11] J. Sorensen, B. B. Jorgensen and N. P. Revsbech, "A Comparison of Oxygen, Nitrate and Sulfate Respiration in Coastal Marine Soil," Microbial Ecology, Vol. 5, No. 2, 1979, pp. 105-111. doi:10.1007/BF02010501

[12] D. R. Lovley and M. J. Klug, "Intermediary Metabolism of Organic Matter in the Soil of a Eutrophic Lake," Applied Environmental Microbiology, Vol. 43, 1982, pp. 552-560.

[13] R. Mohanraju and R. Natarajan, "Methanogenic Bacteria in Mangrove Soils," Hydrobiologia, Vol. 247, No. 1-3, 1992, pp. 187-193. doi:10.1007/BF00008218

[14] C. R. Wang, Y. Shi, X. M. Yang, J. Wu and J. Yue, “Advances of Study on Atmospheric Methane Oxidation (Consumption) in Forest Soil," Journal of Forestry Research, Vol. 14, No. 3, 2003, pp. 230-238. doi:10.1007/BF02856837

[15] C. B. Teri and K. F. Mary, "Linking Microbial Community Composition and Soil Processes in a California Annual Grassland and Mixed Conifer Forest," Biogeochemistry, Vol. 73, No. 2, 2005, pp. 395-415. doi:10.1007/s10533-004-0372-y

[16] R. H. Riley, M. Peter and P. M. Vitousek, "Nutrient Dynamics and Nitrogen Trace Gas Flux during Ecosystem Development in Montane Rain Forest," Ecology, Vol. 76, No. 1, 1995, pp. 292-304. doi:10.2307/1940650

[17] A. L. Ramanathan, G. Singh, J. Majumder, A. C. Samal, R. Chowhan, R. K. Rayan, K. Roykumar and S. C. Santra, 
"A Study of Microbial Diversity and Its Interaction with Nutrients in the Soils of Sundarban Mangroves," Indian Journal of Marine Science, Vol. 37, No. 2, 2008, pp. 159-165.

[18] F. K. Sahrani, Z. Ibrahim, A. Yahya and M. Aziz, "Isolation and Identification of Marine Sulfate Reducing Bacteria Desulfovibrio sp and Citrobacter freundii from Pasir Gudang, Malaysia," Sains Malyasiana, Vol. 37, No. 4, 2008, pp. 365-371.

[19] K. Grasshoff, M. Ehrhardt and K. Kremling, "Standard Methods for Sea Water Analysis," 2nd Edition, WileyVCH, Weinheim, 1983.

[20] S. A. B. Mussa, H. S. Elferjani, F. A. Haroun and F. F. Abdelnabi, "Determination of Available Nitrate, Phosphate and Sulfate in Soil Samples" International Journal of PharmTech Research, Vol. 1, 2009, pp. 598-604.

[21] S. C. Tiwari, B. K. Tiwari and R. R. Mishra, "Microbial Community, Enzyme Activity and $\mathrm{CO}_{2}$ Evolution in Pineapple Orchard Soil," Tropical Ecology, Vol. 30, No. 2, 1989, pp. 265-273.

[22] A. Walkley and J. A. Black, "An Examination of Degtjareff Method for Determining Soil Organic Matter, and a Proposed Modification of the Chromic Acid Titration Method," Soil Science, Vol. 37, No. 1, 1934, pp. 29-38. doi:10.1097/00010694-193401000-00003

[23] L. A. Richards, "Diagnosis and Improvement of Saline and Alkali Soils," USDA Hand Book No. 60, Oxford and IBH Publishing Co., New Delhi, 1968.

[24] A. Pidello and L. J. Monrozier, "Inoculation of the Redox Effector Pseudomonas Fluorescens C7R12 Strain Affects Soil Redox Status at the Aggregate Scale," Soil Biology \& Biochemistry, Vol. 38, No. 6, 2006, pp. 1396-1402. doi:10.1016/j.soilbio.2005.10.010

[25] S. M. Wahid, M. S. Babel and A. R. Bhuiyan, "Hydrologic Monitoring and Analysis in the Sundarbans Mangrove Ecosystem, Bangladesh," Journal of Hydrology, Vol. 332, No. 3-4, 2007, pp. 381-395. doi:10.1016/i.jhydrol.2006.07.016

[26] P. B. Ghosh, B. N. Singh, C. Chakroborty, A. Saha, R. L. Das and A. Choudhury, "Mangrove Litter Production in a Tidal Creek of Lothian Island of Sundarbans, India," Indian Journal of Marine Sciences, Vol. 19, 1990, pp. 292293.

[27] C. Hu and Z. P. Cao, "Size and Activity of the Soil Microbial Biomass and Soil Enzyme Activity in Long Term Field Experiments," World Journal of Agricultural Sciences, Vol. 3, No. 1, 2007, pp. 63-70. 